\title{
The Use of Technology to Facilitate Authentic Learning
}

\author{
Virginia M. MacEntee and Shirley J. Wells \\ SUNY at Oswego, Oswego, NY, USA
}

macentee@oswego.edu

\begin{abstract}
The Use of Technology to Facilitate Authentic Learning will discuss the rationale for developing authentic learning assignments that use technology and allow students to be engaged in exploration and inquiry. Constructivists believe that the most effective way for students to acquire knowledge is to apply that knowledge or instruction to resolve problems that are common to their experience. Therefore, these assignments involve real-world projects that are both relevant and interesting to the learner. Students become involved in an effort to influence an audience beyond their classroom. The Power Point Presentations and the Brochures are developed for their peers and for an audience outside the class (their host teachers and schools).
\end{abstract}

Keywords: technology, authentic learning, pre-service teachers, inclusive education, constructivist learning

\section{Introduction}

Teacher educators today are faced with the responsibility of preparing pre-service teachers to integrate technology into instruction to enhance learning. The National Council for Accreditation of Teacher Education (NCATE), one of the professional governance groups that oversee teacher education programs in the United States, speaks to the need for teachers to be prepared to integrate technology into instruction effectively (NCATE, 2002). Albee (2003) noted that our technological-based society is advancing at such a rapid pace that universities are struggling to prepare students with the technology skills needed for today. Studies have shown that many preservice teachers are not prepared to use technology and integrate it into the curriculum. The Milliken Exchange and ISTE (Moursund \& Bielefeldt, 1999) as cited in Albee (2003) stated that "in order to increase the technology proficiency of new teachers in K-12 classrooms, training institutions should increase the level of technology integration in their own academic programs," (p.54). The National Education Technology Plan (2005) notes that teachers have more resources available through technology than ever before, but have not received sufficient training in the effective use of technology to enhance learning. Their recommendations for states, districts and individual schools include improving the preparation of new teachers in the use of technology (http://www.nationaledtechplan.org/actionsteps.asp\#imp . The International Society for Technology in Education (ISTE) states that all candidates seeking certification or endorsements in teacher

Material published as part of these proceedings, either on-line or in print, is copyrighted by Informing Science. Permission to make digital or paper copy of part or all of these works for personal or classroom use is granted without fee provided that the copies are not made or distributed for profit or commercial advantage AND that copies 1) bear this notice in full and 2) give the full citation on the first page. It is permissible to abstract these works so long as credit is given. To copy in all other cases or to republish or to post on a server or to redistribute to lists requires specific permission from the publisher at Publisher@InformingScience.org preparation should meet the following educational technology standards:

"Teachers demonstrate a sound understanding of technology operations and concepts... Teachers implement curriculum plans that include methods and strategies for applying technology to maximize student learning." 
http://cnets.iste.org/docs/NETS T.doc (p.1). It is the responsibility of faculty across the university and at cooperating schools to provide opportunities for teacher candidates to meet these standards.

Teacher educators today are also faced with the responsibility of preparing pre-service teachers to work in inclusive settings that are increasingly diverse. The Individuals with Disabilities Education Act (IDEA) Amendments (1997) have placed greater emphasis on the role of the general education teacher in instructing students with disabilities in inclusive settings. Because many children with disabilities may receive most of their instruction in general education classrooms, all teachers, whether trained in special education or not, must be prepared to work with exceptional students. The National Council for Accreditation of Teacher Education (NCATE) and the Council for Exceptional Children (CEC), two of the professional governance groups that oversee early education and special education teacher education programs in the United States, speak to the need for teachers to be prepared to meet the needs of a diverse community of students who have different learning styles and come from diverse backgrounds (CEC, 2001; NCATE, 2002). Future teachers need to be prepared to not only provide quality curriculum and effective teaching, but they must be able to access current information that supports their efforts to meet the needs of students with disabilities, students who are culturally and linguistically diverse, and students who demonstrate other areas of exceptionality. The Individuals with Disabilities Improvement Act (IDEA) of 2004 includes new requirements that schools provide "high quality pre-service preparation and professional development for all personnel who work with children with disabilities in order to improve the academic achievement and performance of children with disabilities, including the use of scientifically based instructional practices" (http://www.wrightslaw.com/law/idea/ieps.rbi.htm , p.2).

\section{Discussion}

In order to prepare our pre-service teachers (in SPE 304 - Educational Planning for All Students offered at SUNY Oswego during the spring semester 2004) to integrate technology into instruction and effectively meet the needs of diverse students, a series of assignments was developed that embedded a number of best practice pedagogies.

SUNY Oswego's Board of Trustees’ Information Management competency (2004) states, "Students will understand and use basic research techniques... locate, evaluate, and synthesize information from a variety of sources” (p.1). Bonwell \& Eison (1999) suggest that strategies promoting active learning must allow students to become involved in acquiring information (research) and that time for this must be provided within the curriculum. The first assignment required the pre-service teachers to attend a research class at the college library. There the librarian showed them effective search techniques for accessing ERIC and other databases. She discussed the criteria for evaluating information resources both electronic and print and gave them time to explore the databases on their own.

Vygotsky (1978) noted that collaborative learning has a major role in constructive cognitive development. Ellsworth (1994) explains that in collaborative-learning, the learners take on a more active role in the learning process. They become problem-solvers, contributors and discussants. Collaborative learning situations increase cross-cultural awareness, increased interest, focus and synthesis. Lave and Wengner (1991) stated that learning is not a separate and independent activity, but a vital aspect of participation in any community of practice. Shared learning gives students an opportunity to engage in discussion, take responsibility for their own learning, and thus become critical thinkers. The next assignment required the pre-service teachers to explore a series of internet sites concerning exceptionalities, discern the purposes of the sites, decide whether the sites were free of bias, and then share their findings with their particular group. The third assign- 
ment required them to research professional articles concerning exceptionalities and choose one to outline and share with their respective groups.

Constructivist learning and authentic learning are based on students' active participation in problem-solving and critical thinking regarding a learning activity that they find relevant and engaging. These pedagogical approaches allow students to explore, discuss, and meaningfully construct concepts that involve authentic activities and real world problems (Bonwell \& Eison, 1999; Donovan, Bransford \& Pelligrino, 1999; Jonassen, 1991). Alesandrini \& Larson (2002) state that constructivist learning refers to learning that occurs through the process of student-generated creations that maybe be verbal (e.g. summaries, reflections) or visual (e.g. drawings, multimedia productions). They suggest that constructivist activities are easy to recognize because students create a unique product. The culminating assignment required the pre-service teachers, working in small collaborative groups, to choose a specific exceptionality to research. They then developed a thorough description of the exceptionality, determined which proven teaching programs, classroom techniques and modifications of curriculum are currently considered best practice. A special emphasis was placed on researching assistive technologies which play a critical role in making appropriate accommodations for individuals with disabilities. Using this research they developed a power point presentation that was presented first to their classmates and later to practicing teachers during a professional development workshop. Additionally, the groups designed a brochure, which served as a quick reference for teachers, which briefly discussed the significant points of their presentation and provided a current list of web sites (webliography) for teachers to use when conducting their own research.

\section{Conclusion}

Initially, several important rationales drove the development of these assignments. One was to prepare our pre-service teachers to integrate technology into instruction to enhance learning. A second was for our pre-service teachers to develop through research an in depth knowledge of a chosen exceptionality that they could share with their peers. Third, they were to develop critical research skills so that they could generalize those skills into their professional lives. Last, they would model different best practices within the SPE 304 classroom and thus be able to replicate these educational practices in their own classrooms in the future.

There were a number of positive outcomes of these assignments:

- the improved technology competencies of our pre-service teachers,

- their awareness of assistive technologies which help meet the needs of diverse students,

- their development of critical research skills

- their increased ability to critically analyze best practice programs, materials, and techniques,

- their enhanced presentation skills.

Finally, in developing these authentic assignments we had the opportunity through university/public school collaboration to provide multi-faceted learning experiences for our students, and classroom teachers were afforded an educational workshop that met many of their needs in terms of keeping current with research and best practice techniques to use with their diverse student population.

\section{References}

Albee, J. (2003). A study of preservice elementary teachers' technology skill preparedness and examples of how it can be increased. Journal of Technology and Teacher Education, 11 (1), 53-71. 
Alesandrini, K. \& Larson, L. (2002). Teachers bridge to constructivism. Clearing House, 75 (3), 118.

Bonwell, C. C., \& Eison, J. A. (1991). Active learning: Creating excitement in the classroom. Washington, DC: George Washington University, School of Education and Human Development.

Council for Exceptional Children (CEC). (2000). The CEC standards for the preparation of special educators. Arlington, VA: Council for Exceptional Children.

Donovan, M. S., Bransford, J. D., \& Pellegrino, J. W. (Eds.). (1999). How people learn: Bridging research and practice. Washington, DC: National Academy Press.

Individuals with Disabilities Education Act Amendment of 1997, PL 105-17, 20 U.S.C.Section 1400 et seq.

Individuals with Disabilities Education Improvement Act of 2004, Section 1400 as cited in Wrightslaw. Online. Retrieved January 25, 2005 from http://www.wrightslaw.com/law/idea/ieps.rbi.htm

International Society for Technology in Education (ISTE). ISTE national educational technology standards for teachers, p. 1. Retrieved February 21, 2005 from http://cnets.iste.org/docs/NETS_T.doc

Jonassen, D. (1991). Evaluating constructivist learning. Educational Technology, 36 (9), 28-33.

Oswego Board of Trustees (2004). Information management competency. Computer and Information Literacy, 12 (12), 1.

The National Council for Accreditation of Teacher Education (NCATE). (2002). Professional standards for the accreditation of schools, colleges, and departments of education. Washington, DC: NCATE.

The National Education Technology Plan (2005). Retrieved February 15, 2005 from http://www.nationaledtechplan.org/actionsteps.asp\#imp

Vygotsky, L. S. (1978). Mind in society: The development of higher psychological processes. Cambridge, MA: Harvard University Press.

\section{Biographies}

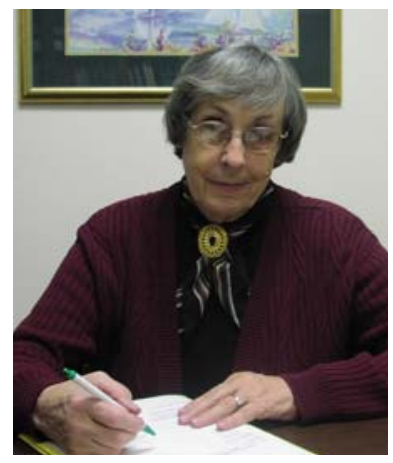

Virginia M. MacEntee, Ed. D. is an assistant professor at the State University of New York at Oswego. She currently works with preservice teachers grades 1-6 to prepare them to work with students with special needs in inclusive settings Dr. MacEntee was a special educator in the public schools of New York for 24 years. She also taught in regular elementary schools in Massachusetts, Virginia, and Alaska.

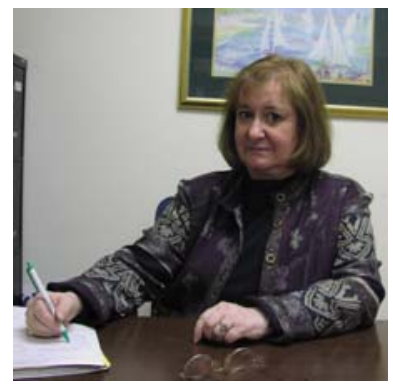

Shirley $\mathbf{J}$. Wells, MS, CAS is a visiting assistant professor in the School of Education at the State University of New York at Oswego. She currently works with pre-service teachers grades 1-6 to prepare them to work in inclusive settings with students with special needs. Professor Wells worked in the public school setting for nearly 30 years and taught in a wide range of settings from special school settings, selfcontained special classes, resource programs and inclusive classrooms. 